California State University, Monterey Bay

Digital Commons@ @ CSUMB

School of Natural Sciences Faculty Publications and Presentations

2013

\title{
Pronounced Genetic Structure in a Highly Mobile Coral Reef Fish, Caesio Cuning, in the Coral Triangle
}

Amanda S. Ackiss

Shinta Pardede

Eric D. Crandall

California State University, Monterey Bay, ecrandall@csumb.edu

Ambariyanto

Ma. Carmen A. Ablan-Lagman

See next page for additional authors

Follow this and additional works at: https://digitalcommons.csumb.edu/sns_fac

\section{Recommended Citation}

Ackiss, A., Pardede, S., Crandall, E.D., Ablan-Lagman, M.A., Ambariyanto, Romena, N., Barber, P.H. and K.E. Carpenter. 2013. Pronounced genetic structure in a highly mobile coral reef fish, Caesio cuning, in the Coral Triangle. Marine Ecology Progress Series 480: 185-197.

This Article is brought to you for free and open access by the School of Natural Sciences at Digital Commons @ CSUMB. It has been accepted for inclusion in School of Natural Sciences Faculty Publications and Presentations by an authorized administrator of Digital Commons @ CSUMB. For more information, please contact digitalcommons@csumb.edu. 


\section{Authors}

Amanda S. Ackiss, Shinta Pardede, Eric D. Crandall, Ambariyanto, Ma. Carmen A. Ablan-Lagman, November Romena, Paul H. Barber, and Kent E. Carpenter 
1 Pronounced genetic structure in a highly mobile coral reef fish, Caesio cuning, in the Coral Triangle

Running head: Genetic structure in Caesio cuning

Amanda S. Ackiss ${ }^{1 *}$, Shinta Pardede ${ }^{2}$, Eric D. Crandall ${ }^{3}$, Ambariyanto $^{4}$, Ma. Carmen A. Ablan-Lagman ${ }^{5}$, November Romena ${ }^{6}$, Paul H. Barber ${ }^{7}$ and Kent E. Carpenter ${ }^{1}$

${ }^{1}$ Old Dominion University, Department of Biological Sciences, Norfolk, VA 23529, USA

${ }^{2}$ Wildlife Conservation Society, Indonesian Marine Program, Bogor 16151, Indonesia

${ }^{3}$ Southwestern Fisheries Science Center, Fisheries Ecology Division, Santa Cruz, CA, USA

${ }^{4}$ Marine Science Department, Faculty of Fisheries and Marine Science, Diponegoro University, Kampus

13 Tembalang, Semarang, Indonesia

$14 \quad{ }^{5}$ De La Salle University, Biology Department, Manila 1004, Philippines

$15{ }^{6}$ Bureau of Fisheries and Aquaculture Research, National Fisheries Research and Development Institute,

16 Quezon City, Philippines

$17{ }^{7}$ University of California Los Angeles, Department of Ecology and Evolutionary Biology, Los Angeles, CA

1890095 , USA

19 *Corresponding author. Email: aackiss@,odu.edu

The redbelly yellowtail fusilier, Caesio cuning, has a tropical Indo-West Pacific range that straddles the Coral Triangle, a region of dynamic geological history and the highest marine biodiversity on the planet. Previous genetic studies in the Coral Triangle indicate the presence of regional limits to connectivity across this region. However, these have focused almost exclusively on benthic reef dwelling species. Schooling, reef-associated fusiliers (Perciformes: Caesionidae) account for a sizable portion of the annual reef catch in the Coral Triangle, yet to date, there have been no in depth studies on the population structure of fusiliers or other mid-water, reef-associated planktivores across this region. We evaluated the genetic population structure of $C$. cuning using a $382 \mathrm{bp}$ segment of the mitochondrial control region amplified from over 620 fish sampled from 33 localities across the Philippines and Indonesia. Phylogeographic analysis showed that individuals sampled from sites in western Sumatra belong to a distinct Indian-Ocean lineage, resulting in pronounced regional structure between western Sumatra and the rest of the Coral Triangle $\left(\Phi_{\mathrm{CT}}=0.4796, \mathrm{p}<0.0043\right)$. We measured additional significant population structure between central Southeast Asia and eastern Indonesia $\left(\Phi_{\mathrm{CT}}=0.0450\right.$, $\mathrm{p}<0.0002$ ). These data in conjunction with spatial analyses indicate that there are two major lineages of $C$. cuning and at least three distinct management units across the region. The location of genetic breaks as well as the distribution of divergent haplotypes across our sampling range suggests that current oceanographic patterns could be

43 Keywords: connectivity, gene flow, isolation by distance, coral reef fish, artisanal 44 fisheries, Coral Triangle 


\section{Introduction}

47 The concentration of marine biodiversity in the Coral Triangle poses both

48 biogeographical questions and management challenges. Straddling the Indo-Malay-

49 Philippine Archipelago and extending eastward to the Solomon Islands, the Coral

50 Triangle is home to the highest diversity of marine organisms in the world (Briggs 1995;

51 Carpenter and Springer 2005; Veron et al. 2009). Coral reef habitat in this region is

52 extensive and complex, rivaling the Great Barrier Reef in area and spanning well over

5325,000 islands. During the Pleistocene epoch, repeated glaciations caused radical changes

54 to the regional geography as the Sunda and Sahul Shelves rose above and fell below the

55 surface of the water (Voris 2000). The exposure of these shelves significantly narrowed

56 the gateway between the tropical Indian and Pacific Oceans, and sea level fluctuations

57 during this epoch have been implicated in numerous studies as a driver of regional

58 population differentiation and speciation across this region (Springer and Williams 1990;

59 Mcmillan and Palumbi 1995; Randall 1998; Lessios et al. 2001; Barber et al. 2006;

60 Crandall et al. 2008a,b; Vogler et al. 2008). At more recent timescales, oceanographic

61 processes have also been implicated in creating and maintaining genetic structure within

62 this region. In particular, the Mindanao and Halmahera eddies, created at the convergence

63 point of the Northern Equatorial Current and the New Guinea Coastal Current, have been

64 hypothesized to limit larval dispersal, and isolate populations across the Maluku sea

65 (Barber et al 2002, 2006, 2011; Kool et al. 2011).

66 Identifying regions of limited connectivity in species that span the Coral Triangle

67 can lead to insights into the stock structure of fisheries for management, as well as

68 mechanisms promoting lineage diversification in this region. Molecular techniques are 
69 particularly useful in highlighting regions where gene exchange does not occur

70 (Hedgecock et al. 2007). Recent reviews indicate the presence of several genetic breaks

71 shared by multiple species across this region, demonstrating that distinct geophysical

72 processes can promote population structure and even lineage diversification within in the

73 Coral Triangle (Carpenter et al. 2011, Barber et al 2011). However, to date the vast

74 majority of reef species showing pronounced genetic structure across the Coral Triangle

75 have been demersal, such as clams, stomatopods, seastars, gastropods and clownfish

76 (Barber et al. 2002, 2006; Crandall et al. 2008a,b; Deboer et al. 2008; Timm and

77 Kochzius 2008; Nuryanto and Kochzius 2009). In contrast, relatively understudied near-

78 shore pelagics give mixed results. The round scad mackeral, Decapterus macrosoma,

79 show very little genetic structure (Borsa 2003), while its congener Decapterus russelli

80 shows up to three genetically structured populations (Rohfritsch and Borsa 2005).

81 Unfortunately the diversity that makes the Coral Triangle an area of evolutionary

82 and biogeographic interest is vulnerable. The region is a hotspot for coral reef threats

83 (Roberts et al. 2002; Nañola et al. 2011). As the human population in this region

84 increases annually by an estimated 1-2\% (US Census Bureau 2011), anthropogenic

85 pressures on coral reef resources continue to rise. Coastal reefs are easily exploitable

86 resources, and reef fish and invertebrates are important sources of food and livelihood in

87 the coastal communities of Southeast Asia (McManus et al. 1992; McManus 1997).

88 Informed management of coral reef ecosystems is a priority for the conservation and

89 sustainability of coral reef resources in the coming decades.

90 The most accepted strategy for improving the biomass and abundance of reef

91 organisms is marine reserves (Roberts and Polunin 1991; Russ and Alcala 1996; 
92 Johannes 2002; Sale 2006). Because dispersive larvae are the primary means of

93 demographic and genetic connectivity among most populations, understanding patterns of

94 larval dispersal has been identified as one of the most critical gaps in developing effective

95 reserve networks (Sale et al. 2005). Although genetic connectivity is not equivalent to

96 demographic connectivity, genetic methods can be of use in guiding conservation

97 planning in marine ecosystems (Palumbi 2003). By identifying regions that are

98 genetically and demographically independent, conservation planners can partition large

99 marine ecosystems into smaller, more tractable management areas for which networks of

100 marine reserves can be designed (Green and Mous 2004). This approach has been

101 specifically proposed as a management mechanism in the Coral Triangle (Carpenter et al.

102 2011).

103 Schooling, reef-associated fusiliers (Perciformes: Caesionidae) are planktivores

104 found feeding at the reef face and account for a sizable portion of harvested reef species

105 in the Coral Triangle. They are caught via a variety of methods including hand-line, fish

106 traps, trawls, drive-in nets and gill nets (Carpenter 1988). In the Philippines alone, the

107 annual catch of caesionids in commercial and municipal fisheries is approximately

10822,000 metric tons (BAS 2010), but given the artisanal nature of most reef fisheries in

109 this region, these catch data are likely greatly underestimated (Alcala and Russ 2002).

110 The red belly yellowtail fusilier, Caesio cuning (Bloch 1791), is a caesionid

111 commonly found in local markets across the Coral Triangle. It is a conspicuous mid-

112 water member of Indo-Pacific reef ecosystems with a distribution that ranges from

113 southern Japan to northern Australia and from Vanuatu to Sri Lanka (Figure 1a). $C$.

114 cuning are schooling, broadcast spawners so there is no reason to suspect sex-biased 
115 dispersal, but beyond this, little is known about the larval ecology of C. cuning. The

116 closest relative with a known pelagic larval duration (PLD) is Pterocaesio chrysozona

117 with an estimated PLD of 37-47 days (Doherty et al. 1995), and there is no evidence to

118 suggest strong larval behavior such as homing (Leis and Carson-Ewart 2003) that may

119 limit dispersal potential. As adults, C. cuning are highly mobile members of the coral reef

120 ecosystem. While they can also be captured in trawls over soft bottom environments

121 (Carpenter 1988) the extent of their movement remains unknown. C. cuning and other

122 fusiliers have been observed sleeping in crevices and holes in the reef structure, however,

123 their level of fidelity to such shelter sites and individual reefs is unclear. The mobility of

124 C. cuning as pelagic larvae coupled with their dependence on reef structure for shelter

125 and undefined movement as adults suggests a varied spectrum of dispersal potential.

126 The purpose of this study is to assess regional genetic connectivity and lineage

127 diversification in Caesio cuning in order to address two questions: (1) are mid-water,

128 reef-associated planktivores impacted by the same barriers we see in demersal species or

129 do they exhibit the panmixia found in near-shore pelagics and (2) if limitations to

130 dispersal in C. cuning are present, can we identify distinct geographic stocks to aid in the 131 management of fusiliers?

132

\section{Methods}

134 We collected 630 Caesio cuning samples from fish markets or by spear while

135 SCUBA or skin diving from 33 localities in the Coral Triangle (Figure 1b). Only samples

136 that were confirmed as being caught on nearby reefs were collected from local markets. 
137 Tissue samples were taken from the pectoral or caudal fin base and preserved in $95 \%$

138 ethanol.

139 DNA amplification and sequencing reactions were conducted at Boston

140 University, the University of the Philippines Marine Science Institute, De La Salle

141 University and Udayana University. Whole genomic DNA was extracted using a 10\%

142 Chelex (Biorad) solution (Walsh et al. 1991). A 382-bp region of the mitochondrial d-

143 Loop was amplified via polymerase chain reaction (PCR) using the forward and reverse

144 primers CR-A and CR-E (Lee et al. 1995). PCR reactions were conducted in a $25 \mathrm{uL}$

145 reaction consisting of $1 \mathrm{uL}$ DNA extraction, $25 \mu \mathrm{L}$ reactions of $2.5 \mu \mathrm{L}$ of $10 \mathrm{x}$ buffer, 2

$146 \mu \mathrm{L} \mathrm{MgCl} 2(25 \mathrm{mM}), 2.5 \mu \mathrm{L}$ dNTPs $(8 \mathrm{mM}), 1.25 \mu \mathrm{L}$ of each $10 \mathrm{uM}$ primer, $1 \mu \mathrm{L}$ of

147 template, and $0.625 \mathrm{U}$ of AmpliTaq (Applied Biosystems). Manual hot start

148 thermocycling parameters were employed as follows: initial hold at $80^{\circ} \mathrm{C}$, denaturation

$14994{ }^{\circ} \mathrm{C}(1 \mathrm{~min})$, main cycle $94^{\circ} \mathrm{C}(30 \mathrm{~s}), 50-52^{\circ} \mathrm{C}(30 \mathrm{~s})$ and $72^{\circ} \mathrm{C}(40 \mathrm{~s})$ for 39 cycles, then

150 a final extension of $72^{\circ} \mathrm{C}(7-10 \mathrm{~min})$.

$151 \quad$ PCR products were electrophoresed on a 1\% agarose gel and visualized with

152 ethidium bromide or SYBR ${ }^{\circledR}$ Green staining. Successful PCR reactions were

153 enzymatically prepared for sequencing by digesting $5 \mathrm{ul}$ of PCR product in $0.5 \mathrm{U}$ of

154 Shrimp Alkaline Phosphatase and $5 \mathrm{U}$ of Exonuclease for 30 minutes at $37^{\circ} \mathrm{C}$ followed by

15515 minutes at $80^{\circ} \mathrm{C}$. Forward and reverse sequencing reactions were performed with Big

156 Dye terminator chemistry and run on an ABI 3730 automated DNA Sequencer (Applied

157 Biosystems). Forward and reverse sequences were proofread in Sequencher ${ }^{\mathrm{TM}} 4.7$ (Gene

158 Codes Corporation, Ann Arbor, Michigan) and all resulting 383-bp fragments were

159 aligned with ClustalX v2.0.12. The online tookit FaBox (Villesen 2007) was used to 
160 reduce our final alignment to unique haplotypes and create an input file for the population

161 genetics data analysis program Arlequin 3.5.12 (Excoffier and Lischer 2010).

162 The species identity of our sampled haplotypes was confirmed with a neighbor-

163 joining tree run in PAUP* (Swofford 2003) that included the three most closely related

164 sister species found across our sampling range as outgroups-Caesio lunaris, Caesio teres

165 and Caesio xanthonota. We examined the frequencies and phylogenetic relatedness of

166 haplotypes in our dataset with a median-joining minimum spanning tree generated in

167 NETWORK v4.6 (Bandelt et al. 1999).

168 For each locality we used DnaSP v5 (Librado and Rozas 2009) to calculate

169 standard genetic diversity indices and tested the null hypothesis of neutrality in the

170 mitochondrial control region using Fu's $\mathrm{F}_{\mathrm{S}}$ and $\mathrm{Fu}$ and Li's D* tests, with significance

171 determined by 1000 simulations of a neutral coalescent model. We employed the latter

172 two statistics to evaluate the potential effects of selection and demographic processes

173 such as population expansion on our data ( $\mathrm{Fu} 1997)$.

174 To investigate the presence of barriers to dispersal and gene flow, we employed

175 both a priori and post hoc analyses. We first used examined population pairwise $\Phi_{\mathrm{ST}}$, and

176 performed an analysis of molecular variance (AMOVA) in Arlequin. For the AMOVA

177 analysis, we grouped sampling localities to test for hierarchical population structure

178 within our dataset following a priori hypotheses based on previously measured

179 phylogeographic breaks (Figure 3; Table 2) as follows: absence of genetic structure,

180 restricted gene flow east and west of the Makassar strait, a Sunda Shelf break at western

181 Sumatra, the Philippines vs. Indonesia, east vs. west of the Maluku Sea, and a break at

182 Cenderawasih Bay in Papua. All AMOVAs were run using sites with $\mathrm{n} \geq 15$ and 
183 employed the Tamura and Nei model of evolution, which was the model in Arlequin

184 most equivalent to the best model for our dataset determined by jModelTest v1.0 (Posada

185 2008; Guindon and Gascuel 2003). The significance of pairwise $\Phi_{\mathrm{ST}}$ as well as among and

186 within population variance in the AMOVA framework was calculated using $30,000+$

187 random permutations of the dataset. The $\mathrm{p}$ values for multiple pairwise comparisons were

188 adjusted using Bonferroni as well as Benjamini and Hochberg's (1995) false discovery

189 rate to reduce Type II error associated with the former method (Narum 2006).

190 In addition we employed a post hoc spatial analysis of the pairwise $\Phi_{\mathrm{ST}}$ matrix

191 generated in Arlequin using the program BARRIER version 2.2 (Manni et al. 2004).

192 BARRIER characterizes the spatial relationship of sites from their GPS coordinates using

193 Voronoi tessellation and Delaunay triangulation and applies Monmonier's maximum

194 difference algorithm to a matrix of genetic distances ( $\Phi_{\mathrm{ST}}$ in this case) to identify genetic

195 barriers across geographic space. We tested the robustness of barriers by resampling

196 individuals within populations with replacement using Excel and creating 100

197 bootstrapped replicates of our pairwise $\Phi_{\mathrm{ST}}$ matrix in Arlequin.

198 Since discrete genetic breaks can bias the results of analyses of Isolation by

199 Distance (IBD) and the presence of isolation by distance can generate false positives in

200 analyses of hierarchical structure (AMOVA) (Meirmans 2012), we employed partial

201 Mantel tests that controlled for both optimal AMOVA clusters and geographic distance

202 using the 'vegan' package for R (Oksanen et al. 2012; R Core Team 2012). Pairwise

203 genetic distances $\left(\Phi_{\mathrm{ST}}\right)$ among localities with $\mathrm{n}>15$ were imported from Arlequin, and

204 negative pairwise $\Phi_{\mathrm{ST}}$ values, a result of within population variance exceeding among

205 population variance, were set to zero. Our geographic distance matrix was generated 
206 using a previously developed Python script that calculates shortest distance over water

207 from the GPS points of sample sites (Etherington 2011) in ArcGIS 9.3. We created a

208 third distance matrix that reflected the hierarchical structure of our best AMOVA

209 grouping by using a zero to code for localities within the same group and a one to code

210 for localities in different groups. We first tested for significant correlations between

211 genetic and geographic distance, using AMOVA group membership as a covariate. We

212 then tested the correlation between genetic distance and AMOVA grouping, using

213 geographic distance as a covariate. Significance was tested with 10,000 random

214 permutations, and the relationships among distances and clusters were plotted.

\section{Results}

217 A total of 625 fish were successfully sequenced at the mitochondrial control

218 region, representing 20 study sites across Indonesia and 13 study sites in the Philippines.

219 When aligned, 129 sites over the amplified $382 \mathrm{bp}$ were polymorphic. There were 393

220 haplotypes, 308 of which were unique to a single individual. The highest frequency

221 haplotype was shared by 18 individuals.

222

223 Phylogenetic Relatedness

224 The unweighted mean pairwise difference between haplotypes in our minimum

225 spanning tree was $11.090 \mathrm{bp}$. All haplotypes from Medan and Padang, with the exception

226 of a single individual from Padang, fell within a divergent clade separated from all other

227 haplotypes by 8 mutational steps (Figure 2a,b). A single individual sampled at Makassar,

228 Sulawesi also fell within this divergent Indian Ocean clade. Regional clustering within 
229 the Pacific lineage shows some evidence that the distribution of haplotypes is non-

230 random.

231

232 Population Structure

233 Haplotype diversity was high, measuring at or near 1 for all localities (Table 1).

234 Our two sites from Sumatra - Medan and Padang - had slightly lower nucleotide diversity

235 (0.0171 and 0.0169 , respectively) compared to all other sites, which had nucleotide

236 diversities ranging from 0.0242 to 0.0356 . While high haplotype diversity and low

237 nucleotide diversity could be an indication of recent population expansion, neither of

238 these sites had significantly negative values for Fu's $F_{s}$ (Table 1). Across all sampled

239 localities, there were only two significant values for Fu and Li's D* which is more

240 sensitive to the effects of background selection ( $\mathrm{Fu}$ 1997). However Fu's $\mathrm{F}_{\mathrm{S}}$, which is

241 more sensitive to signatures of demographic expansion and genetic hitchhiking, was

242 significantly negative at 11 of 13 sites in the Philippines and 14 of 20 sites in Indonesia,

243 indicating that the departures from neutrality can be ascribed to one of these two

244 processes $(\mathrm{Fu} 1997)$.

245 The results of our AMOVA analyses indicate significant genetic structuring in

246 Caesio cuning across the Coral Triangle (Table 2; $\left.\Phi_{\mathrm{ST}}=0.1421, \mathrm{p}<0.00001\right)$. Grouping

247 sites east and west of the Makassar Strait accounted for a non-significant portion of the

248 genetic variance between groups measured at this locus whereas grouping our two

249 western Sumatra sites separately from all others accounted for $47.96 \%$ of the genetic

250 variance $\left(\Phi_{\mathrm{CT}}=0.0258, \mathrm{p}<0.08554\right.$ vs. $\left.\Phi_{\mathrm{CT}}=0.4796, \mathrm{p}<0.00426\right)$. Since the variance

251 generated by spatially explicit, divergent clades can overwhelm signatures of structure 
252 within a dataset, we removed Medan and Padang from further AMOVA analyses. When

253 the remaining sites from the Pacific Clade were split into a Philippines' group and an

254 Indonesian group, the $\Phi_{\mathrm{CT}}$ was significant but only explained $0.09 \%$ of the variance

255 between groups $\left(\Phi_{\mathrm{CT}}=0.0091, \mathrm{p}<0.02246\right)$. Splitting sites east and west of the Maluku

256 Sea gave us our optimal partition and accounted for $4.50 \%$ of the variance between

257 groups $\left(\Phi_{\mathrm{CT}}=0.0450, \mathrm{p}<0.00023\right)$. When this partition was shifted to Cenderawasih

258 Bay, it remained significant accounting for slightly less variance between groups $\left(\Phi_{\mathrm{CT}}=\right.$

$2590.0420, p<0.00083)$. These patterns of genetic structure were echoed in the pairwise $\Phi_{\text {ST }}$

260 values calculated for each pair of sampling localities (tables attached as supplemental).

261 Of the five tested breaks across the Coral Triangle, $C$. cuning exhibits two commonly

262 found in reef-associated, demersal species: a Sunda Shelf break at western Sumatra

263 (partition 2, Figure 3) and a break near the Maluku Sea in eastern Indonesia (partition 4,

264 Figure 3).

265 Spatial analysis of our pairwise $\Phi_{\text {ST }}$ matrix showed good agreement with our $a$

266 priori AMOVA results. Bootstrapping analyses reached their highest confidence values

267 when parameters were set to four barriers across the entire dataset (where $\mathrm{n} \geq 15$ ). A

268 barrier between the polygon space of Medan and Padang and all other sites is always the

269 first to be placed by BARRIER and carries unanimous bootstrap support (1.00) regardless

270 of number of designated barriers (Figure 4a). The second barrier is found in the region of

271 Halmahera and the Maluku Sea, which carries the next highest confidence values (0.78-

272 0.80; Figure 4b). The third barrier was complex and found in the Philippines with the

273 most supported divisions between the southern Philippines and eastern Indonesia (0.49-

274 0.60; Figure 4c). The fourth barrier divided the Philippines from central Indonesia, but 
275 was supported by less than half of our bootstrap replicates (0.44; Figure $4 \mathrm{~d})$. While the

276 third and fourth barriers partition more variance in our dataset, neither carries strong

277 enough bootstrap support to be viewed with any confidence.

279 Isolation by Distance

280 When all localities $(\mathrm{n} \geq 15)$ were included in our IBD analysis, points associated 281 with the western Sumatran sites Medan and Padang clustered separately from other sites

282 (Figure 5a). To avoid bias arising from their uniquely divergent lineage coupled with

283 their location on the edge of our sampling range, these two localities were excluded from

284 further IBD analyses. When we ran a Mantel test of only the localities within the Pacific

285 lineage, our results showed that there is a significant indication of IBD within this Pacific

286 lineage (Figure 5b, dashed line). We measured a $\mathrm{Z}$ of 8964.2023 and a correlation

287 coefficient (r) of 0.4216 with a corresponding p-value of less than 0.0001 .

288 Despite the correlation between genetic and geographic distance, our plot

289 indicated that there were still sites nearly $3000 \mathrm{~km}$ apart within the Pacific lineage that

290 exhibited no measurable genetic differences. Since our AMOVA analyses indicate the

291 presence of hierarchical structure, we ran partial Mantel tests to determine the nature of

292 the significant correlation we measured. A partial Mantel test examining the correlation

293 of geographic distance to pairwise $\Phi_{\mathrm{ST}}$ while accounting for our optimal AMOVA

294 clusters (central Indonesia and the Philippines vs. sites in the Bird's Head region of

295 Papua) resulted in a non-significant correlation coefficient ( $\mathrm{r})$ of $0.1642(\mathrm{p}<0.0657)$. A

296 partial Mantel test examining the correlation of pairwise $\Phi_{\text {ST }}$ to the location of sites

297 within one or the other of our two optimal sites while accounting for geographic distance 
298 resulted in an $\mathrm{r}$ of $0.5907(\mathrm{p}<0.0002)$, indicating the hierarchical clustering of our sites

299 explains a significant percentage of the variance in our dataset while isolation by distance

300 does not. This is further supported by a Mantel test of only sites within the Philippines

301 and central Indonesia cluster (we were unable to run a Mantel test on the eastern

302 Indonesia cluster since all pairwise $\Phi_{\mathrm{ST}}=0$ ). We measured a $\mathrm{Z}$ of 2093.5389 and a

303 correlation coefficient ( $r$ ) of 0.1258 with a non-significant p-value of 0.1306 (Figure 5b,

304 dotted line).

305

306 Discussion

307 Patterns of genetic structure in a mid-water planktivore

308 Hierarchical genetic analyses revealed two significant regions of genetic structure 309 across the Coral Triangle in the coral reef fish, Caesio cuning. A sharp genetic break was

310 observed across the Sunda Shelf barrier, echoing patterns reported from a diversity of

311 reef taxa including groupers, giant clams, crown-of-thorns seastars, damselfishes,

312 surgeonfish and snappers (Craig et al. 2007; Timm et al. 2008; Vogler et al. 2008; Drew

313 and Barber 2009; Eble et al. 2010; Gaither et al. 2010). Such population divergence

314 across the Sunda shelf is frequently attributed to historical vicariance between Pacific and

315 Indian Ocean populations during Pleistocene low sea level stands (e.g. Barber et al. 2000;

316 Rohfritsch and Borsa 2005; Deboer et al. 2008). In addition, significant departures from

317 neutrality, as measured by Fu's $F_{S}$, indicate the lingering effects of a Pleistocene

318 population expansion onto the Sunda and Sahul Shelves as sea levels rose during the Last

319 Glacial Maximum. Similar departures have been seen in every species examined in this

320 region so far (see Crandall et al. 2012). Shared phylogeographic patterns such as these 
321 result from broadly acting physical processes that shape genetic patterns in codistributed

322 taxa (Avise 2000). However, the maintenance of these patterns in modern times, despite

323 the lack of physical isolation, likely results from oceanographic currents or reproductive

324 isolation between the two lineages.

325 During the northeast monsoon, the Southern Equatorial Counter Current (SECC)

326 bifurcates off the coast of southern Sumatra (Schott and McCreary 2001). During the

327 southwest monsoon, this reverses, and where Sumatra meets Java, a southeastern flow

328 hits a northwesterly flowing current that is driven by the Indonesian Throughflow. Both

329 monsoonal patterns have the potential to create a barrier to continuous gene flow at the

330 site of bifurcation and conjunction (Figure 2c), potentially reinforcing isolation during

331 periods of lowered sea levels. Support for this hypothesis comes from a recent

332 quantitative analysis using biophysical models coupled with matrix projection (Kool et al.

333 2011) that predicts the genetic isolation of populations in the Andaman Sea and western

334 Sumatra.

335 While studies of many reef organisms indicate divergence between Pacific and

336 Indian Ocean populations, only a few have sampled at a scale fine enough to illuminate

337 the extent and location of overlap between these divergent lineages (e.g. Barber et al.

338 2002, 2006; Crandall et al. 2008a,b; Deboer et al. 2008; Nuryanto and Kochzius 2009;

339 Gaither et al. 2011). The overlap between divergent Indian and Pacific Ocean lineages in

340 Caesio cuning is surprisingly small for such a potentially mobile fish. Haplotype

341 distributions from our minimum spanning tree indicate very limited gene flow between

342 the northern tip of Java and equatorial Sumatra - a distance of just over $800 \mathrm{~km}$. No

343 landmass or geographical feature separates the waters of Padang (Sumatra) from the two 
344 closest sample sites on Java, Anyer and Kepulauan Seribu, yet only a single individual

345 unites the maternal lineages of Padang to these two sites (Figure 2c). While regional

346 oceanographic patterns could be limiting the genetic connectivity in C. cuning across this

347 region, it is notable that across the same geographic range, the anenomefish Amphiprion

348 ocellaris shows greater admixture of Indian and Pacific maternal lineages in the Java Sea

349 (Timm and Kochzius 2008), and anenomefishes have a larval dispersal period of only 8-

35012 days (Fautin and Allen 1992) and larvae exhibit natal homing (Jones et al. 2005).

351 Given the limited overlap of our two lineages, reproductive isolation between the clades

352 cannot be ruled out as a possible explanation for the absence of gene flow in this region.

353 In addition to the phylogeographic break observed at the Sunda shelf, significant

354 limits to genetic exchange were also seen in eastern Indonesia. At first pass, a significant

355 correlation between genetic distance and over-water distance suggests that limits to gene

356 flow in this region might be due a stepping-stone model of gene flow in which nearby

357 localities exchange more migrants than they do with distant localities (Figure 5b).

358 However, our partial Mantel tests clearly show that this appearance of isolation-by-

359 distance is actually an artifact of hierarchical structure between the two regions delimited

360 by BARRIER and AMOVA analysis (Figures 3 \& 4; Table 2).

361 This genetic structuring across the Maluku Sea mirrors genetic structure and even

362 pronounced phylogeographic breaks east and west of Halmahera found in two species of

363 giant clam (Deboer et al. 2008; Nuryanto and Kochzius 2009) and 14 species of

364 stomatopods (Barber et al. 2006; Barber et al. 2011), suggesting this region may be

365 important for lineage diversification. While Caesio cuning populations on either side of

366 Halmahera are not characterized by distinct clades as is seen in western Indonesia, the 
367 minimum spanning tree indicates some non-random, regional clustering of haplotypes.

368 Frequency differences among related haplotypes within the Pacific Ocean clade may be

369 caused by isolation facilitated by two eddies generated at the convergence point of the

370 Northern Equatorial Current and the New Guinea Coastal Current, the Mindanao Eddy

371 and the Halmahera Eddy (Figure 2c). The Halmahera Eddy has previously been

372 suggested as important for driving lineage diversification in the region of the Maluku Sea

373 (Barber et al 2002, 2006, 2011), however, both eddies direct a significant amount of flow

374 back into the Pacific Ocean, so both may be contributing to genetic isolation observed in

375 population genetic and computer modeling studies (Kool et al. 2011) conducted in this

376 region.

377 The recovery of multiple regions of significant genetic structure in Caesio cuning

378 is somewhat surprising because the high mobility potential of adults could result in

379 genetic admixture, such as the signal of secondary contact seen in migratory Decapterus

380 macrosoma (Borsa 2003). However, the concordance of our data to phylogeographic

381 patterns of demersal reef species with larval dispersal as well as to biophysical models of

382 larval dispersal (Kool et al. 2011) suggests that adult C. cuning are site-attached, and that

383 the major avenue of genetic connectivity in C. cuning is via larval dispersal. If adults are

384 truly site-attached, C. cuning would be dependent on larval dispersal to maintain gene

385 flow among populations across its range.

Implications for management

388 As a significant artisanal fishery in the Coral Triangle, Caesio cuning is subject to

389 anthropogenic population declines. A study of Sumilon Island in the Philippines 
390 documented changes in reef fish density after protective management was removed for a

391 quarter of the island's reefs. Alcala and Russ (1990) measured a 64\% decrease in

392 caesionid density after an eighteen-month period of fishing by approximately 100 local

393 fishermen from an adjacent island using hand-paddled canoes. Given that artisanal

394 fishing of caesionids has been shown to cause precipitous drops in local abundance, a

395 better understanding of stock structure is particularly important for the management of $C$. 396 cuning.

397 The results of this study suggest that Caesio cuning populations in the Philippine

398 and Indonesian portions of the Coral Triangle should be best viewed as at least three

399 stocks. However, managing a reef fishery at this scale is complex because these stocks do

400 not conform to national borders. We saw no significant genetic divergence across sites in

401 the Philippines and central Indonesia that are nearly $3000 \mathrm{~km}$ apart (see pairwise $\Phi_{\text {ST }}$

402 table, supplemental material). This connectivity is likely facilitated by the Indonesian

403 Throughflow, a strong current originating in the Western Pacific that flows between

404 Kalimantan and Sulawesi and empties into the Indian Ocean via three major

405 "chokepoints" - the Bali-Lombok Strait, the Ombai Strait and the Timor Passage (Figure

406 2c). Dispersal simulations have predicted a net flow of larvae north to south via this

407 pathway (Kool et al. 2011). The boundaries among stocks in western, central and eastern

408 Indonesia all occur within Indonesian national borders, which potentially simplifies

409 management planning and authority. However, the absence of genetic structure between

410 the Philippines and central Indonesia implies that the diversity and abundance of larvae

411 produced from Philippine reefs could have an important impact on the sustainability and

412 genetic diversity of reefs of central Indonesia. This interdependence between countries 
413 within the Coral Triangle emphasizes the importance of developing informed,

414 multinational management plans such as the Coral Triangle Initiative

415 (www.coraltriangleinitiative.org).

$416 \quad$ Future work should focus on fine scale sources and flow of larvae both within

417 regions of high genetic connectivity as well as areas of restricted gene flow in order to

418 ensure continual replenishment of coral reef resources. In the case of Caesio cuning,

419 particular attention should be given to areas with evidence of severely limited gene flow

420 such as the junction of Sumatra and Java. Determining the nature of the limited overlap

421 between the two mitochondrial clades will be key to the proper management design in

422 this region. Mitochondrial genetic studies do not have the power to detect reproductive

423 isolation with certainty, so future study should incorporate bi-parentally inherited nuclear

424 DNA. Multiple independent genetic markers such as microsatellites or SNPs could be

425 applied to extended sampling in this area to detect whether it is cryptic speciation or

426 barriers to genetic connectivity maintaining this break. It is particularly important to

427 identify whether gene flow is restricted, since intense overfishing in such a region could

428 result in temporary local extinctions. Until future research characterizes the nature and

429 direction of genetic connectivity across these regions, our understanding of the

430 population structure of $C$. cuning is limited to large scales.

\section{Acknowledgements}

433 We thank the governments of the Philippines and Indonesia for supporting this research

434 collaboration. We thank the University of the Philippines Marine Science Institute, De La

435 Salle University, Udayana University, A. Juinio-Meñez and N. Mahardika for hosting 
436 laboratory work essential to this research. These collaborations were made possible by

437 two grants from NSF: OISE-0730256 to K. E. Carpenter and P. H. Barber and NSF OCE-

4380349177 to P.H. Barber. Additional funding for this project was provided to S. Pardede

439 from the Christensen Fellowship, Dr. T. Parkinson, and the Wildlife Conservation

440 Society. The National Fisheries Research and Development Institute (NFRDI) and the

441 U.S. Peace Corps in the Philippines, and the Indonesian Ministry for Research and

442 Technology (RISTEK) and the Indonesian Institute of Sciences (LIPI) in Indonesia

443 assisted with collection permits and/or field logistics. Sampling in Indonesia was covered

444 under permits 1187/SU/KS/2006, 04239/SU.3/KS/2006, and 0119/FRPSM/VI/2009.

445 This work was aided by G. Allen, G. Batin, J. Drew, M. Erdmann, A. Hanson, D. Pada,

446 R. Rachmawati, J. Raynal, C. Starger, and C. Yusuf. We wish to acknowledge J.

447 Sanciangco and E. Stump for their technical support and anonymous reviewers for their

448 suggestions for improvement of this manuscript.

\section{$450 \quad$ References}

451 Alcala A, Russ G (2002) Status of Philippine coral reef fisheries. Asian Fish Sci 15:177-

$452 \quad 192$

453 Ballantine B (1997) Design principles for systems of 'no take' marine reserves.

454 Proceedings at The Design and Monitoring of Marine Reserves. Fisheries Center,

455 University of British Columbia, Vancouver. pp1-24

456 Bandelt H-J, Forster P, Röhl A (1999) Median-joining networks for inferring

$457 \quad$ intraspecific phylogenies. Mol Biol Evol 16:37-48 
458 Barber PH, Palumbi SR, Erdmann MV, Moosa MK (2000) A marine Wallace's line?

$459 \quad$ Nature 406:692-693

460 Barber PH, Palumbi SR, Erdmann MV, Moosa MK (2002) Sharp genetic breaks among

461 populations of Haptosquilla pulchella (Stomatopoda) indicate limits to larval

462 transport: patterns, causes and consequences. Mol Ecol 11:659-674

463 Barber PH, Erdmann MV, Palumbi SR (2006) Comparative phylogeography of the three

464 codistributed stomatopods: origins and timing of regional lineage diversification

465 in the coral triangle. Evolution 60:1825-1839

466 Barber, P.H., Cheng, S.H., Erdmann, S.E. Tengardjaja, K., Ambariyanto. (2011)

467 Evolution and conservation of marine biodiversity in the Coral Triangle: insights

468 from stomatopod Crustacea In: Held, C., S. Koenemann \& C.D. Schubart (eds),

469 Crustacean Issues 19 Phylogeography and Population Genetics in Crustacea pp.

470 129-156; CRC Press.

471 Barber, P.H. (2009) The challenge of understanding the Coral Triangle biodiversity

472 hotspot. J Biogeogr 36:260-265.

473 Benjamini Y, Hochberg Y (1995) Controlling the false discovery rate: a practical and

474 powerful approach to multiple testing. J R Stat Soc Series B (Methodological)

$475 \quad 57: 289-300$

476 Bloch ME (1791) Naturgeschichte der auslandischen Fische, Berlin

477 Borsa P (2003) Genetic structure of the round scad mackeral Decapterus macrosoma

478 (Carangidae) in the Indo-Malay archipelago. Mar Biol 142:575-581

479 Briggs JC (1995) Global biogeography. Elsevier, Amsterdam; New York 
480 Bureau of Agricultural Statistics (2010) Fisheries statistics of the Philippines 2007-2009.

$481 \quad$ pp $1-416$

482 Cabin RJ, Mitchell RJ (2000) To Bonferroni or not to Bonferroni: when and how are the 483 questions. Bull Eco Soc Am 81:246-248

484 Carpenter K (1988) FAO species catalogue. Vol. 8. Fusilier fishes of the world. An 485 annotated and illustrated catalogue of caesionid species known to date. FAO Fish $486 \quad$ Synop 875

487 Carpenter KE, Springer VG (2005) The center of the center of marine shore fish 488 biodiversity: the Philippine Islands. Environ Bio Fish 72:467-480

489 Carpenter KE, Barber PH, Crandall ED, Ablan-Lagman MCA, Ambariyanto, Mahardika 490 GN, Manjaji-Matsumoto BM, Juinio-Meñez MA, Santos MD, Starger CJ, Toha 491 AHA (2011) Comparative phylogeography of the coral triangle and implications 492 for marine management. Journal of Marine Biology 2011

493 Craig MT, Eble JA, Bowen BW, Robertson DR (2007) High genetic connectivity across 494 the Indian and Pacific Oceans in the reef fish Myripristis berndti (Holocentridae). $495 \quad$ Mar Ecol Prog Ser 334:245-254

496 Crandall ED, Jones ME, Muñoz MM, Akinrobe B, Erdmann MV, Barber PH (2008a)

497 Comparative phylogeography of two seastars and their ectosymbionts within the $498 \quad$ coral triangle. Mol Ecol 17:526-5290

499 Crandall ED, Frey M, Grosberg R, Barber PH (2008b) Contrasting demographic history 500 and phylogeographical patterns in two Indo-Pacific gastropods. Mol Ecol 17:611$501 \quad 626$ 
502 Crandall ED, Sbrocco EJ, DeBoer TS, Barber PH, Carpenter KE (2012) Expansion

503 Dating: Calibrating Molecular Clocks in Marine Species from Expansions onto

504 the Sunda Shelf Following the Last Glacial Maximum. Mol Biol Evol 29: 707-

$505 \quad 719$

506 Deboer TS, Subia M, Erdmann MV, Kovitvongsa K, Barber PH (2008) Phylogeography

507 and limited genetic connectivity in the endangered boring giant clam across the

508 Coral Triangle. Conserv Biol 22:1255-1266

509 Doherty PJ, Planes S, Mather P (1995) Gene flow and larval duration in seven species of

$510 \quad$ fish from the Great Barrier Reef. Ecology 76:2373-2391

511 Drew J, Barber PH (2009) Sequential cladogenesis of the reef fish Pomacentrus

512 moluccensis (Pomacentridae) supports the peripheral origin of marine biodiversity

513 in the Indo-Australian archipelago. Mol Phylogenet Evol 53:335-339

514 Eble JA, Rocha LA, Craig MT, Bowen BW (2010) Not All Larvae Stay Close to Home:

515 Insights into Marine Population Connectivity with a Focus on the Brown

516 Surgeonfish (Acanthurus nigrofuscus). Journal of Marine Biology:1-12

517 Etherington TR (2011) Python based GIS tools for landscape genetics: visualising genetic

518 relatedness and measuring landscape connectivity. Methods in Ecology and

$519 \quad$ Evolution 2:52-55

520 Excoffier L, Lischer HEL (2010) Arlequin suite ver 3.5: A new series of programs to

521 perform population genetics under Linux and Windows. Mol Ecol Resources

$522 \quad 10: 564-567$

523 Fautin DG, GR Allen (1992) Field guide to anemone fishes and their host sea anemones.

524 Perth: Western Australian Museum 
525 Fu YX (1997) Statistical tests of neutrality of mutations against population growth, 526 hitchhiking and background selection. Genetics 147:915

527 Gaither MR, Toonen RJ, Robertson DR, Planes S, Bowen BW (2010) Genetic evaluation

528 of marine biogeographical barriers: perspectives from two widespread Indo-

529 Pacific snappers (Lutjanus kasmira and Lutjanus fulvus). J Biogeogr 37:133-147

530 Gaither MR, Bowen BW, Bordenave T-R, Rocha LA, Newman SJ, Gomez JA, van

531 Herwerden L, and Craig MT ( 2011) Phylogeography of the reef fish

532 Cephalopholis argus (Epinephelidae) indicates Pleistocene isolation across the

533 indo-pacific barrier with contemporary overlap in the coral triangle. Evol Biol

$534 \quad 11: 189$

535 Green A, Mous P (2004) Delineating the Coral Triangle, its ecoregions and functional 536 seascapes. Proceedings of The Nature Conservancy Expert Workshop p24

537 Guindon S, Gascuel O (2003) A simple, fast and accurate method to estimate large 538 phylogenies by maximum-likelihood. Sys Biol 52: 696-704

539 Hedgecock D, Launey S, Pudovkin A, Naciri Y, Lapègue S, Bonhomme F (2007) Small

540 effective number of parents $(\mathrm{Nb})$ inferred for a naturally spawned cohort of

541 juvenile European flat oysters Ostrea edulis. Mar Biol 150:1173-1182

542 Jensen JL, Bohonak AJ, Kelley ST (2005) Isolation by distance, web service. BMC

$543 \quad$ Genetics 6: 13.v.3.23 http://ibdws.sdsu.edu/

544 Johannes RE (2002) The renaissance of community-based marine resource management

545 in Oceania. Annu Rev Ecol Syst 33:317-340

546 Jones GP, Planes S, Thorrold SR (2005) Coral reef fish larvae settle close to home. Curr $547 \quad$ Biol 15:1314-1318 
548 Kool JT, Paris CB, Barber PH, Cowen RK (2011) Connectivity and the development of

549 population genetic structure in Indo-West Pacific coral reef communities. Glob

550 Ecol Biogeogr 5:695-706

551 Lee W, Conroy J, Howell W, Kocher T (1995) Structure and evolution of teleost

552 mitochondrial control regions. J Mol Evol 41:54-66

553 Leis JM, Carson-Ewart BM (2003) Orientation of pelagic larvae of coral-reef fishes in 554 the ocean. Mar Ecol Prog Ser 252:239-253

555 Lessios H, Kessing BD, Pearse JS (2001) Population structure and speciation in tropical 556 seas: global phylogeography of the sea urchin Diadema. Evolution 55:955-975

557 Librado P, Rozas J (2009) DnaSP v5: A software for comprehensive analysis of DNA 558 polymorphism data. Bioinformatics 25:1451-1452

559 Manni F, Guérard E, Heyer E (2004) Geographic patterns of (genetic, morphologic,

560 linguistic) variation: how barriers can be detected by "Mononier's algorithm."

$561 \quad$ Hum Biol 76: 173-190.

562 McManus JW (1997) Tropical marine fisheries and the future of coral reefs: a brief

563 review with emphasis on Southeast Asia. Coral Reefs 16:121-127

564 McManus JW, Nañola CL, Reyes RB, Kesner KN (1992) Resource Ecology of the

565 Bolinao Coral Reef System. International Center for Living Aquatic Resources

$566 \quad$ Management, Manila

567 Mcmillan WO, Palumbi SR (1995) Concordant evolutionary patterns among Indo-West

568 Pacific butterflyfishes. Proc R Soc Biol Sci 260:229-236

569 Meirmans PG (2012) The trouble with isolation by distance. Mol Ecol 21: 2839-2846 
570 Nakagawa S (2004) A farewell to Bonferroni: the problems of low statistical power and $571 \quad$ publication bias. Behav Ecol 15:1044

572 Nañola CL, Aliño PM, Carpenter KE (2011) Exploitation-related reef fish species

573 richness depletion in the epicenter of marine biodiversity. Environ Biol Fish

$574 \quad 90: 405-420$

575 Narum SR (2006) Beyond Bonferroni: less conservative analyses for conservation

576 genetics. Conserv Genet 7:783-787

577 Nuryanto A, Kochzius M (2009) Highly restricted gene flow and deep evolutionary

578 lineages in the giant clam Tridacna maxima. Coral Reefs 28:607-619

579 Oksanen JF, Blanchet G, Kindt R, Legendre P, Minchin PR, O'Hara RB, Simpson GL,

580 Solymos P, Stevens MHH, Wagner H (2012) vegan: Community Ecology Package.

581 R package version 2.0-4. http://CRAN.R-project.org/package=vegan

582 Palumbi SR (2003) Population genetics, demographic connectivity, and the design of

583 marine reserves. Ecol Appl 13:146-158

584 Posada D (2008) jModeltest: Phylogenetic Model Averaging. Mol Biol Evol. 25: 125-

$585 \quad 1256$

586 R Core Team (2012) R: A language and environment for statistical computing. R

$587 \quad$ Foundation for Statistical Computing. Vienna, Austria. ISBN

588 3-900051-07-0. http://www.R-project.org

589 Randall JE (1998) Zoogeography of shore fishes of the Indo-Pacific region. Zool Stud $590 \quad 37: 227-268$

591 Roberts CM, Polunin NVC (1991) Are marine reserves effective in management of reef 592 fisheries? Rev Fish Biol Fish 1:65-91 
593 Roberts CM, McClean CJ, Veron JEN, Hawkins JP, Allen GR, McAllister DE,

594 Mittermeier CG, Schueler FW, Spalding M, Wells F, Vynne C, Werner TB

595 (2002) Marine biodiversity hotspots and conservation priorities for tropical reefs.

$596 \quad$ Science 295:1280

597 Rofritsch A, Borsa P (2005) Genetic structure of Indian scad mackerel Decapterus

598 russelli: Pleistocene vicariance and secondary contact in the Central Indo-West

$599 \quad$ Pacific seas. Heredity 95:315-326

600 Russ G, Alcala A (1996) Do marine reserves export adult fish biomass? Evidence from

601 Apo Island, central Philippines. Mar Ecol Prog Ser 132:1-9

602 Sale PF, Cowen RK, Danilowicz BS, Jones GP, Kritzer JP, Lindeman KC, Planes S,

603 Polunin NVC, Russ GR, Sadovy YJ (2005) Critical science gaps impede use of

604 no-take fishery reserves. Trends Ecol Evol 20:74-80

605 Sale PF (2006) The science we need to develop for more effective management. In: Sale

606 PF (ed) Coral reef fishes: dynamics and diversity in a complex ecosystem.

$607 \quad$ Academic Press pp361-376

608 Schott FA, McCreary JP (2001) The monsoon circulation of the Indian Ocean. Prog

$609 \quad$ Oceanogr 51:1-123

610 Springer VG, Williams JT (1990) Widely distributed Pacific plate endemics and lowered

$611 \quad$ sea-level. Bull Mar Sci 47:631-640

612 Swofford DL (2003) PAUP*. Phylogenetic Analysis Using Parsimony (*and Other

613 Methods). Sinauer Associates, Sunderland, MA 
614 Timm J, Kochzius M (2008) Geological history and oceanography of the Indo-Malay

615 Archipelago shape the genetic population strucutre in the false clown

616 anemonefish (Amphiprion ocellaris). Mol Ecol 17:3999-4014

617 Timm J, Figiel M, Kochzius M (2008) Contrasting patterns in species boundaries and

618 evolution of anemonefishes (Amphiprioninae, Pomacentridae) in the centre of

619 marine biodiversity. Mol Phylogenet Evol 49:268-276

620 US Census Bureau (2011) Intenational Statistics: Population by Country or Area: 1332.

621 Statistical Abstract of the United States. US Census Bureau, pp836-838

622 http://www.census.gov/compendia/statab/cats/international_statistics.html

623 Veron JEN, DeVantier LM, Turak E, Green AL, Kininmonth S, Stafford-Smith M,

624 Peterson N (2009) Delineating the coral triangle. Galaxea, Journal of Coral Reef

$625 \quad$ Studies 11:91-100

626 Villesen P (2007) FaBox: an online toolbox for fasta sequences. Mol Ecol Notes 7:965-

$627 \quad 968$

628 Vogler C, Benzie J, Lessios H, Barber P, Wörheide G (2008) A threat to coral reefs

629 multiplied? Four species of crown-of-thorns starfish. Biology Letters 4:696

630 Voris H (2000) Special Paper 2: Maps of Pleistocene Sea Levels in Southeast Asia:

631 Shorelines, River Systems and Time Durations. J Biogeogr 27:1153-1167

632 Walsh PS, Metzger DA, Higuchi R (1991) Chelex 100 as a medium for simple extraction

633 of DNA for PCR-based typing from forensic material. BioTechniques 10:506-513

634 Wijffels SE, Meyers G, Godfrey JS (2008) A 20-yr average of the Indonesian

635 throughflow: regional currents and the interbasin exchange. J Phys Oceanogr 38

636 


\section{$640 \quad$ Figures}

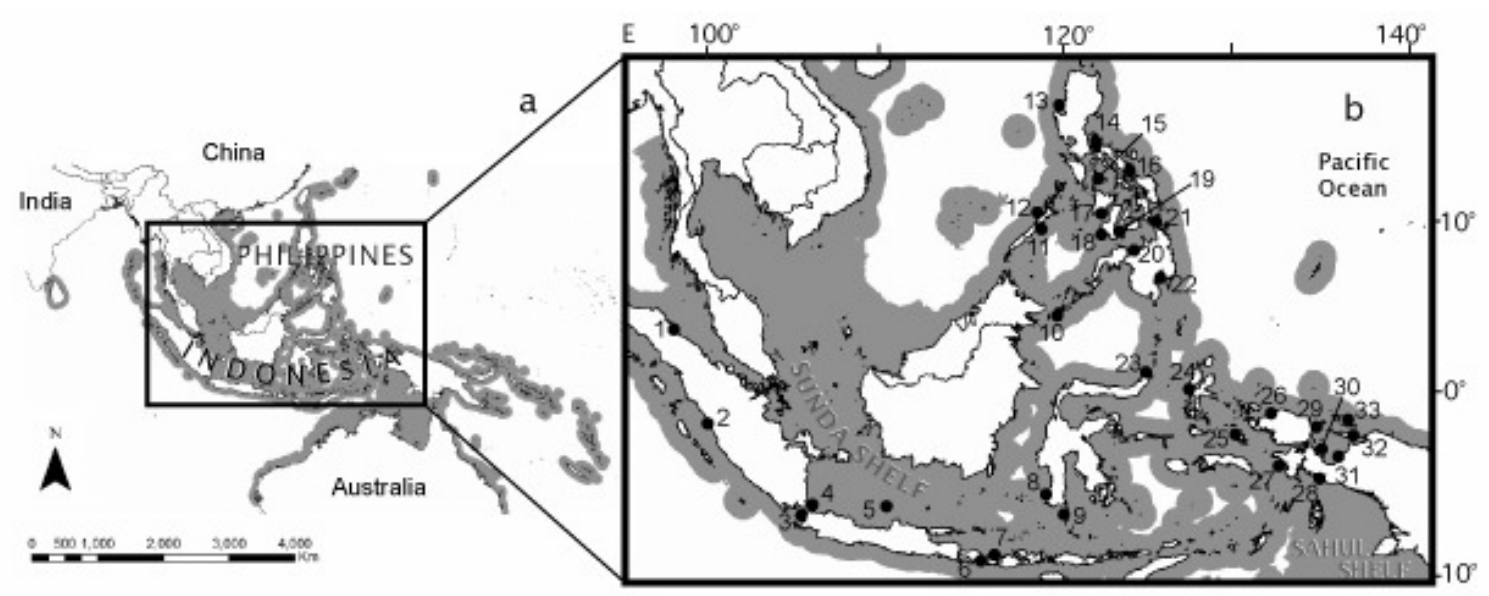

643 Figure 1 a. The distribution of Caesio cuning. b. Inset. Sampling localities of this study:

644 Medan (1), Padang (2), Anyer (3), Seribu (4), Karimunjawa (5), Bali (6), Lombok (7), 645 Makassar (8), Selayar (9), Tawi Tawi (10), Honda Bay (11), Ulugan Bay (12), Bolinao 646 (13), Perez (14), Romblon (15), Sorsogon (16), Guimaras (17), Negros Occidental (18), 647 Negros Oriental (19), Balingasag (20), Dinagat (21), Davao (22), Manado (23),

648 Halmahera (24), Raja Ampat (25), Sorong (26), Fak Fak (27), Kaimana (28), Manokwari 649 (29), Windesi - Teluk Cenderawasi (30), Karei - Teluk Cenderawasi (31), Yapen (32), 650 Biak (33). 


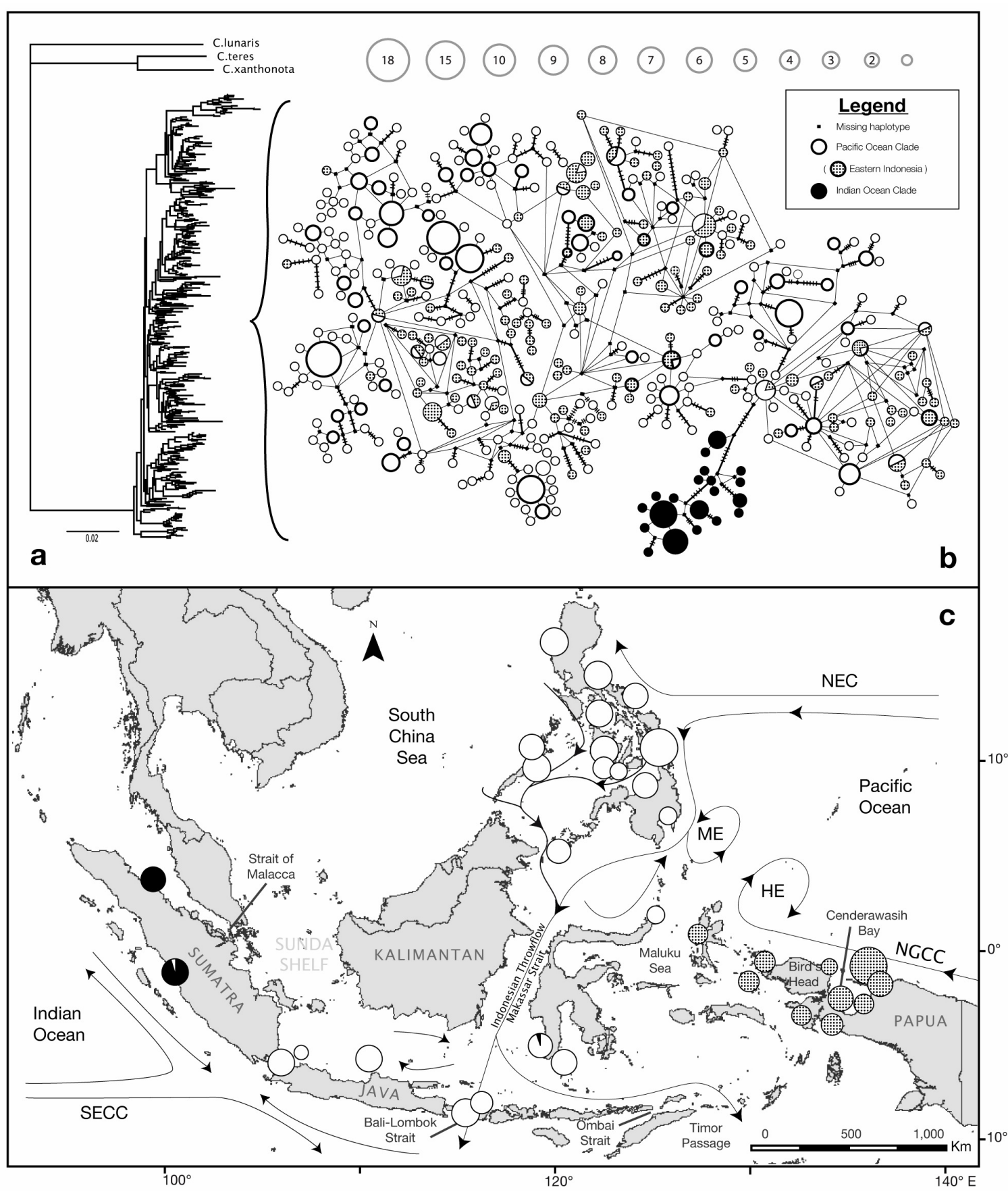

Figure 2. a. Neighbor-joining analysis depicting the relationship of our sampled Caesio

654 cuning haplotypes to the three most closely related Caesio spp. in the region. $\mathbf{b}$.

655 Minimum spanning tree for mitochondrial control region haplotypes of Caesio cuning.

656 Gray shading highlights the eastern Indonesian sites within the Pacific Clade, which

657 uncorrected pairwise $\Phi_{\mathrm{ST}} \mathrm{S}$ and optimal AMOVA partitioning indicate are significantly

658 different from other sites in this clade. c. Geographic distribution of regional genetic

659 structure. Area of circles is relative to total number of individuals sampled at each site; 
660 sizes range from $n=46$ (Dinagat, Philippines) to $n=7$ (Pulau Seribu, Indonesia). Major

661 oceanographic features are labeled, including the Northern Equatorial Current (NEC), the

662 New Guinea Coastal Current (NGCC), the Halmahera Eddy (HE), Mindanao Eddy (ME)

663 and the Southern Equatorial Countercurrent (SECC).

664

665

666

667

668

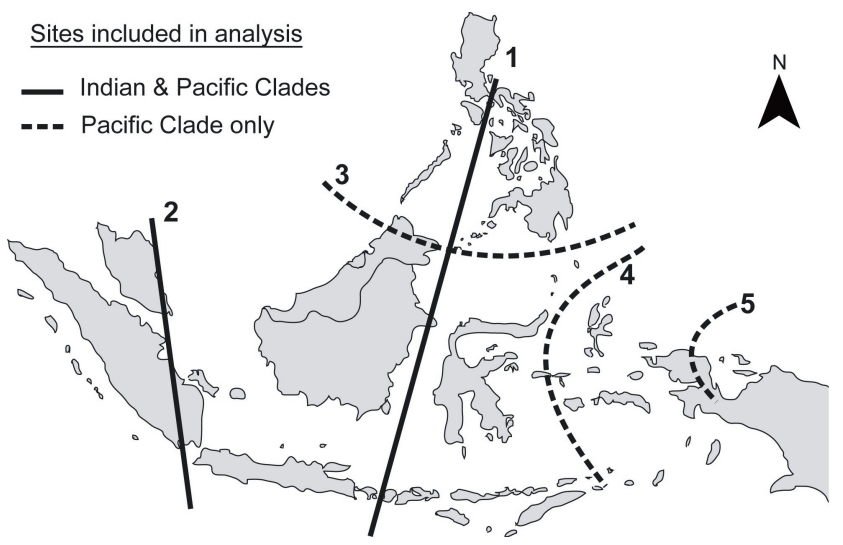

669 Figure 3. AMOVA Hypotheses Lines indicate the approximate locations of regional

670 genetic breaks found in the mtDNA of other well-sampled coral reef and near reef species

671 across the Coral Triangle (see Table 2). Solid lines indicate partitions tested with a

672 hierarchical analysis of molecular variance that included sites from both the Indian and

673 Pacific clades; dashed lines indicate partitions tested within the Pacific clade only.

674

675

676

677

678

679

680

681

682 


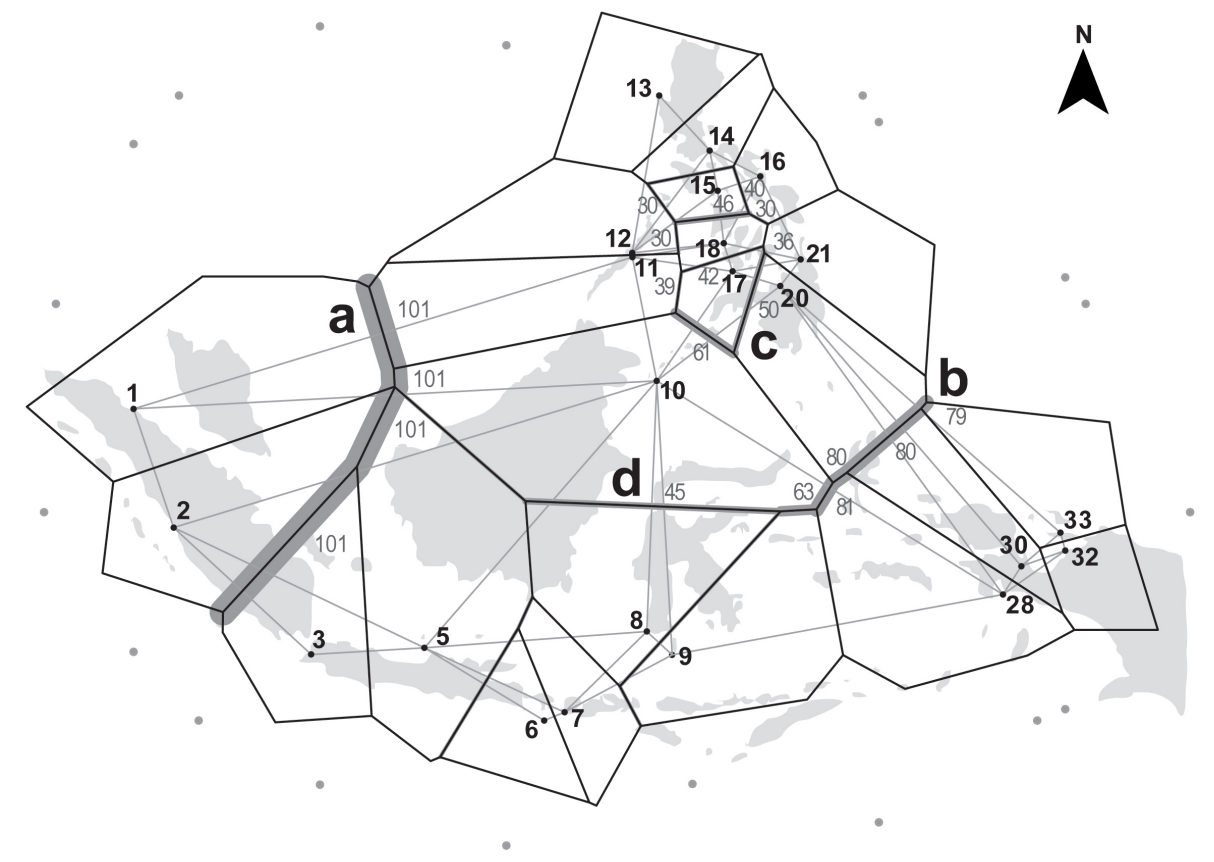

683

684 Figure 4. BARRIER Analysis Spatial analysis of sites $(\mathrm{n} \geq 15)$ with four barriers

685 designated (results labelled a-d) and corresponding confidence values labeled in gray

686 (100 bootstrap replicates +1$)$. Black polygons indicate Voronoi tessellation, gray lines

687 indicate Delaunay triangulation. Thickness of barriers is relative to bootstrap support.

688

689

690 


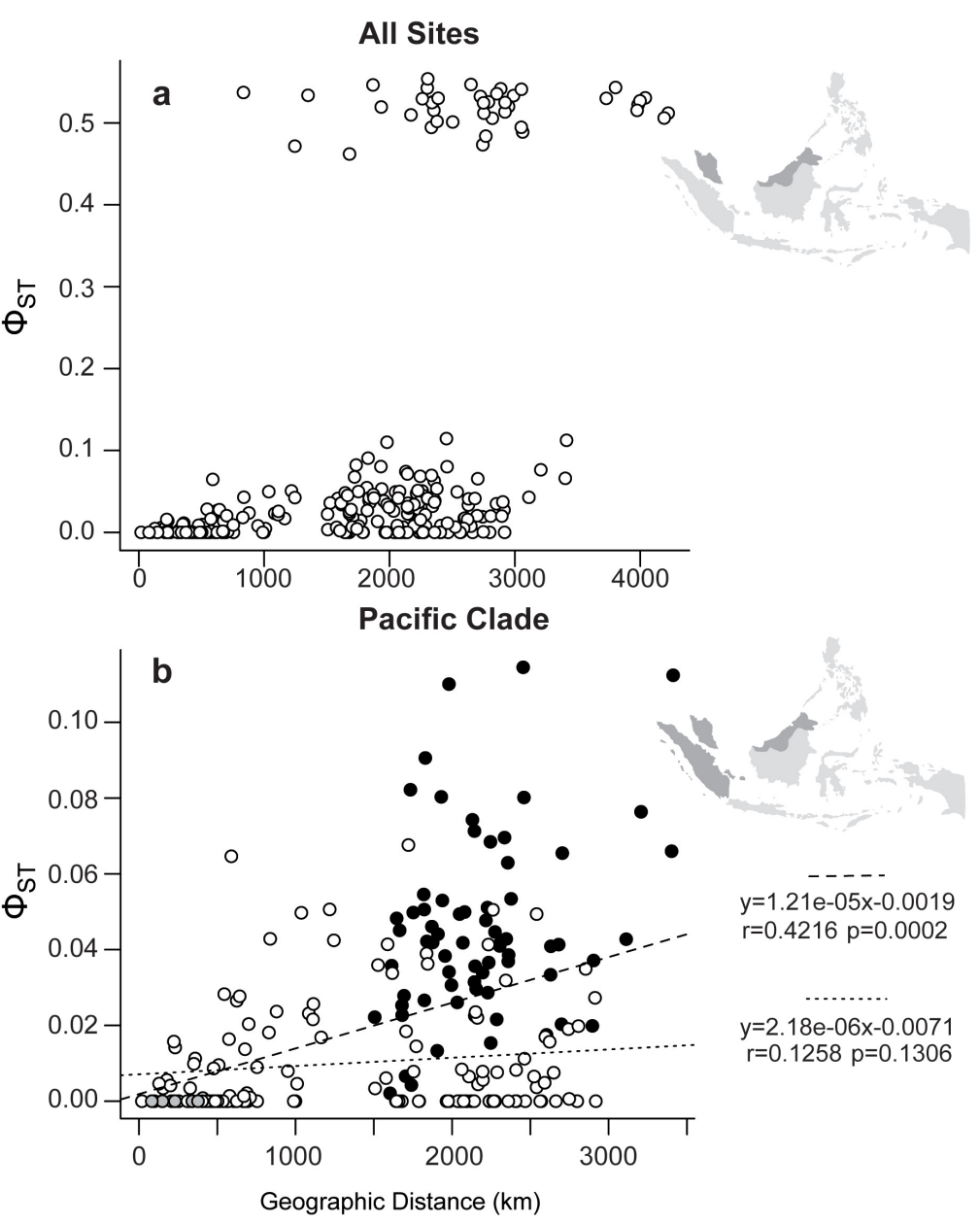

692 Figure 5. Isolation By Distance graphs Comparison of pairwise $\Phi_{\mathrm{ST}}$ to geographic

693 distance for a. all sites with sample sizes greater than 15, showing clustering of Medan

694 and Padang associated with their spatial orientation and divergent clade, and b. Pacific

695 Clade only. Black dots are pairwise comparisons between sites belonging to different

696 AMOVA clusters, white dots are comparisons between sites within the Philippines and

697 central Indonesia cluster, and gray dots are comparisons between sites within the eastern

698 Indonesia cluster (all $\Phi_{\mathrm{ST}}=0$ ). The dashed line is the regression for all sites in the Pacific

699 Clade (significant due to presence of hierarchical structure), and the dotted line is the

700 regression for only sites across the Philippines and central Indonesia (white dots only;

701 non-significant).

702

703

704 
707 Table 1. Molecular diversity indices for Caesio cuning: $\mathbf{n}=$ number of samples, hap =

708 number of unique haplotypes, $\boldsymbol{h}=$ haplotype diversity, $\boldsymbol{\Pi}=$ nucleotide diversity, $\boldsymbol{\theta}_{\mathrm{s}}=$

709 theta estimated using the number of segregating sites, and Fu's $\mathbf{F}_{\mathrm{S}}$ and Fu and Li's $\mathbf{D}^{*}=$

710 two neutrality statistics.

\begin{tabular}{|c|c|c|c|c|c|c|c|c|}
\hline & Sampling Locality & $\mathbf{n}$ & hap & $\boldsymbol{h}$ & II & $\boldsymbol{\theta}_{\mathrm{s}}$ & $\mathbf{F}_{\mathbf{S}}$ & $D^{*}$ \\
\hline 1 & Medan & 20 & 12 & 0.921 & 0.017 & 6.765 & -1.641 & -1.118 \\
\hline 2 & Padang & 22 & 13 & 0.918 & 0.017 & 8.778 & -2.168 & $-2.081^{*}$ \\
\hline 3 & Anyer & 22 & 19 & 0.983 & 0.026 & 10.973 & $-7.154^{*}$ & -0.322 \\
\hline 4 & Seribu & 7 & 7 & 1 & 0.024 & 9.796 & -1.725 & -0.565 \\
\hline 5 & Karimunjawa & 20 & 20 & 1 & 0.034 & 15.503 & $-10.469^{*}$ & -0.072 \\
\hline 6 & Bali & 26 & 22 & 0.982 & 0.026 & 10.482 & $-8.891^{*}$ & -0.239 \\
\hline 7 & Lombok & 16 & 15 & 0.992 & 0.029 & 11.452 & $-5.286^{*}$ & -0.481 \\
\hline 8 & Makassar & 18 & 18 & 1 & 0.027 & 13.665 & $-10.237 *$ & -0.993 \\
\hline 9 & Selayar & 20 & 15 & 0.942 & 0.025 & 10.429 & -3.034 & -0.794 \\
\hline 10 & Tawi Tawi & 17 & 13 & 0.963 & 0.027 & 10.944 & -1.984 & -0.644 \\
\hline 11 & Honda Bay & 26 & 23 & 0.991 & 0.028 & 11.793 & $-10.162 *$ & -0.349 \\
\hline 12 & Ulugan Bay & 21 & 19 & 0.991 & 0.026 & 10.562 & $-8.230 *$ & -0.047 \\
\hline 13 & Bolinao & 24 & 24 & 1 & 0.027 & 10.712 & $-16.723 *$ & -0.527 \\
\hline 14 & Perez & 25 & 24 & 0.997 & 0.026 & 11.388 & $-15.200^{*}$ & -0.415 \\
\hline 15 & Romblon & 17 & 17 & 1 & 0.028 & 10.649 & $-9.056^{*}$ & -0.237 \\
\hline 16 & Sorsogon & 19 & 18 & 0.994 & 0.025 & 10.872 & $-9.019 *$ & -0.369 \\
\hline 17 & Negros Occidental & 15 & 14 & 0.991 & 0.025 & 10.457 & $-5.352 *$ & -0.767 \\
\hline 18 & Guimaras & 26 & 25 & 0.997 & 0.027 & 12.579 & $-15.492 *$ & -1.044 \\
\hline 19 & Negros Oriental & 8 & 8 & 1 & 0.030 & 12.342 & -1.933 & -0.609 \\
\hline 20 & Balingasag & 21 & 19 & 0.990 & 0.024 & 11.952 & $-8.981 *$ & -0.446 \\
\hline 21 & Dinagat & 46 & 44 & 0.998 & 0.024 & 13.197 & $-43.847^{*}$ & -1.489 \\
\hline 22 & Davao & 9 & 9 & 1 & 0.025 & 10.302 & -2.911 & -0.533 \\
\hline 23 & Manado & 9 & 8 & 0.972 & 0.025 & 10.670 & -1.157 & -0.849 \\
\hline 24 & Halmahera & 12 & 11 & 0.985 & 0.029 & 9.934 & -2.627 & 0.494 \\
\hline 25 & Raja Ampat & 13 & 10 & 0.949 & 0.026 & 10.312 & -0.918 & -0.633 \\
\hline 27 & Fak Fak & 11 & 11 & 1 & 0.023 & 10.584 & $-4.636^{*}$ & -0.797 \\
\hline 28 & Sorong & 14 & 14 & 1 & 0.025 & 9.434 & $-6.906^{*}$ & -0.409 \\
\hline 28 & Kaimana & 16 & 16 & 1 & 0.026 & 9.644 & $-8.432 *$ & 0.037 \\
\hline 29 & Manokwari & 8 & 8 & 1 & 0.031 & 12.727 & -1.853 & -0.436 \\
\hline 30 & Windesi - Teluk Cenderwasi & 20 & 19 & 0.995 & 0.026 & 10.429 & $-9.444^{*}$ & -0.591 \\
\hline 31 & Karei - Teluk Cenderwasi & 13 & 13 & 1 & 0.024 & 10.634 & $-6.112 *$ & -0.765 \\
\hline 32 & Yapen & 21 & 19 & 0.991 & 0.025 & 9.728 & $-8.330^{*}$ & -0.293 \\
\hline 33 & Biak & 43 & 36 & 0.991 & 0.024 & 13.174 & $-24.146^{*}$ & $-1.963^{*}$ \\
\hline
\end{tabular}

$711 *$ denotes significant values of Fu's Fs and Fu and Li's D* $(\alpha=0.05)$. 
714 Table 2. AMOVA Summary. Unstandardized results of AMOVA tests with localities

715 where $\mathrm{n} \geq 15$ using 30,000+ random permutations. Tested partitions are labeled 1-5

716 corresponding to illustrations in Figure 3. The first three analyses include both lineages,

717 while the lower three analyses examine genetic structure within the Pacific Clade. K

718 values give the number of groupings tested. P-values $\leq 0.05$ indicate significant statistics,

719 and optimal partitions for each group of analyses are bolded. The last column "e.g." lists

720 pelagic and demersal species that exhibit phylogeographic breaks in mtDNA on which

721 our hypotheses for partitioning are based.

\begin{tabular}{|c|c|c|c|c|c|c|c|}
\hline & Hypothesis & Sites & St & istic & $\mathbf{p}$ & $\%$ var & e.g. \\
\hline \multicolumn{8}{|c|}{ Both Clades (Indian \& Pacific) } \\
\hline \multirow{3}{*}{\multicolumn{2}{|c|}{$k=1$}} & & - & - & - & - & \\
\hline & & 23 & - & - & - & - & Decapterus macrosoma (Borsa 2003) \\
\hline & & & $\boldsymbol{\Phi}_{\mathrm{ST}}$ & 0.1421 & 0.00001 & 14.21 & \\
\hline \multirow{3}{*}{1} & \multirow{3}{*}{$\begin{array}{c}k=2 \text {; east vs. west of } \\
\text { the Makassar Strait }\end{array}$} & & $\boldsymbol{\Phi}_{\mathrm{CT}}$ & 0.0258 & 0.08554 & 2.58 & \multirow{3}{*}{ Decapterus russelli (Rofristch and Borsa 2009) } \\
\hline & & 23 & $\boldsymbol{\Phi}_{\mathrm{SC}}$ & 0.1312 & 0.00001 & 12.78 & \\
\hline & & & $\boldsymbol{\Phi}_{\mathrm{ST}}$ & 0.1537 & 0.00001 & 84.64 & \\
\hline & \multirow{3}{*}{$\begin{array}{c}k=2 ; \text { Western Sumatra } \\
\text { vs. all other sites }\end{array}$} & \multirow{3}{*}{23} & $\boldsymbol{\Phi}_{\mathrm{CT}}$ & 0.4796 & 0.00426 & 47.96 & \multirow{3}{*}{$\begin{array}{l}\text { Dascyllus trimaculatus (Leray et al. 2010) } \\
\text { Acanthaster planci (Vogler et al. 2008) } \\
\text { Tridacna crocea (Deboer et al. 2008) } \\
\text { Nerita albicilla (Crandall et al. 2008b) }\end{array}$} \\
\hline & & & $\boldsymbol{\Phi}_{\mathrm{SC}}$ & 0.0189 & 0.00003 & 0.98 & \\
\hline & & & $\boldsymbol{\Phi}_{\mathrm{ST}}$ & 0.4894 & 0.00001 & 51.06 & \\
\hline \multicolumn{8}{|c|}{ Pacific Clade } \\
\hline & \multirow{3}{*}{$\begin{array}{c}k=2 ; \text { Philippines vs. } \\
\text { Indonesia }\end{array}$} & \multirow{3}{*}{21} & $\Phi_{\mathrm{CT}}$ & 0.0091 & 0.02246 & 0.091 & \multirow{3}{*}{ Hippocampus kuda (Lourie et al. 2005) } \\
\hline & & & $\boldsymbol{\Phi}_{\mathrm{SC}}$ & 0.0140 & 0.00136 & 1.39 & \\
\hline & & & $\boldsymbol{\Phi}_{\mathrm{ST}}$ & 0.0229 & 0.00007 & 97.71 & \\
\hline \multirow{3}{*}{4} & \multirow{3}{*}{$\begin{array}{c}k=2 ; \text { central } C T \text { vs. } \\
\text { eastern Indonesia at } \\
\text { Halmahera }\end{array}$} & \multirow{3}{*}{21} & $\Phi_{\mathrm{CT}}$ & 0.0450 & 0.00023 & 4.50 & \multirow{3}{*}{$\begin{array}{c}\text { Tridacna crocea (Deboer et al. 2008) } \\
\text { Haptosquilla glyptocercus (Barber et al. 2006) }\end{array}$} \\
\hline & & & $\boldsymbol{\Phi}_{\mathrm{SC}}$ & 0.0026 & 0.27264 & 0.25 & \\
\hline & & & $\Phi_{\mathrm{ST}}$ & 0.0474 & 0.00003 & 95.25 & \\
\hline \multirow{3}{*}{5} & \multirow{3}{*}{$\begin{array}{l}k=2 ; \text { central CT vs. } \\
\text { eastern Indonesia at } \\
\text { Cenderawasih Bay }\end{array}$} & \multirow{3}{*}{21} & $\boldsymbol{\Phi}_{\mathrm{CT}}$ & 0.0420 & 0.00083 & 4.20 & \multirow{3}{*}{$\begin{array}{l}\text { Haptosquilla pulchella (Barber et al. 2006) } \\
\text { Tridacna maxima (Nuryanto and Kochzius 2009) } \\
\text { Protoreaster nodosus (Crandall et al. 2008a) }\end{array}$} \\
\hline & & & $\boldsymbol{\Phi}_{\mathrm{SC}}$ & 0.0056 & 0.11032 & 0.54 & \\
\hline & & & $\boldsymbol{\Phi}_{\mathrm{ST}}$ & & 0.00003 & 95.26 & \\
\hline
\end{tabular}

